\title{
Paramastoid apophysis: case report
}

\author{
LINS, C.C.S.A. ${ }^{*}$, AMORIN JÚNIOR, A.A. ${ }^{1}$, VILLAROUCO, F.M.O. ${ }^{1}$, \\ GATIS, M.C.Q. ${ }^{1}$ and TAVARES, R.M.C. ${ }^{1}$
}

\author{
${ }^{1}$ Department of Anatomy, Federal University of Pernambuco - UFPE. \\ Av. Moraes Rego, 1235, CEP 50670-901, Cidade Universitária, Recife, PE, Brazil. \\ *E-mail: cabralcarlal@hotmail.com
}

\begin{abstract}
The aim of this study was to report a case of a paramastoid apophysis of a human skull, identified during routine lessons at the Laboratory of Human Anatomy, Federal University of Pernambuco and Recife-PE, Brazil. The skull used in this study showed a morphological variation present only on the right side of the occipital bone, which had a height of $18.10 \mathrm{~mm}$ and had a facet joint with the transverse process of the atlas, being identified as paramastoid apophysis. Other anatomical variations in skull were found as: presence of sutural bone along the lambdoidal suture and persistent metopic suture. Thus, this study will be important for the health sciences and those who keep interest in pathologies associated with atlanto-occipital joint, because the description of the structures that deviate from the normal organogenesis resulting from disorders: hereditary basis or not, has a practical interest that prints the modification to the arrangement of the constituent elements of the region and possible functional alterations resulting therefrom.
\end{abstract}

Keywords: anatomy, anatomic variation, occipital bone.

\section{Introduction}

The skull is at the top of the axial skeleton. Originating from embryonic mesenchyme located around the brain. It consists in two different regions: the neurocranium and viscerocranium which comprises the bones which form the openings of the respiratory and digestive system called facial skeleton (MOORE, DALLEY and AGUR, 2011).

The occipital bone is part of neurocranium, it forms the larger part of the back and base of the skull, it is trapezoid and internally concave. It is divided into squama, basilar part, and side parts (condylar); these located inferiorly articulate with the facet joints of the atlas. Among the anatomical accidents of the occipital is located the jugular process, projecting laterally from the posterior half of each condyle, where is inferiorly inserted the lateral rectus muscle of the head, which may be found in this region the paramastoid process, which is inferiorly projected with the possibility of linking up with the transverse process of the atlas (WILLIAMS et al., 1995). Thus, the objective of this study was to report the morphological appearance of an apophysis paramastoid of a human skull, and comment on the importance of knowledge of the same in the possible surgical-clinical implications in atlanto-occipital joint.

\section{Case Report}

During routine lessons for Undergraduate Course of Dentistry, Federal University of Pernambuco, Recife-PE, Brazil, in the Laboratory of Anatomy was observed in a human skull, caucasian, about approximately 40 years of age, the presence of a variation anatomic on the right side of occipital bone, identified as paramastoid apophysis. This had a circular base with a cylindrical body that in the transverse direction decreased in diameter in the direction base-apex, beyond this, in the apex was found a facet joint that articulates with the transverse process of the atlas (Figures 1 and 2). We performed the measurement of the structure using a pachymeter with an accuracy of $0.05 \mathrm{~mm}$ according to Mandarim-de-Lacerda (1995) obtaining a length of $18.10 \mathrm{~mm}$ of elevation (Figure 3 ). Other anatomical variations were found in the skull as: presence of sutural bone along the lambdoidal suture and persistent metopic suture.

\section{Discussion}

According to Mascitti and Strejilevich (1961) the presence of the paramastoid apophysis in the human occipital bone was first described by Meckel in 1815. For the authors the term paramastoid was given by Macalisher (no quotes the year) and is taken as synonymous paraoccipital, parajugular, paracondylar, apophysis jugular or estiloid. The authors also affirmed that its frequency was described initially by Chaine 1920 and it ranges from 0.7 to $1 \%$ in human skulls.

Le Double (1903) reported that the apophysis paramastoid can provide a non-articular variety, which is associated with the more frequent arrangement or the articular in relation to the transverse apophysis of the atlas, but any of both types may be present unilaterally or bilaterally. According to Amadei (1880) to be considered as paramastoid apophysis it has to exceed in six millimeters of elevation.

In a study by Mascitti and Strejilevich (1961) in 196 skulls in the collection of morphology of Juan Jose Naon, National Hospital of Neuropsychiatry of Men (Argentina), were found in four human skulls of caucasian individuals, aged 40 to 50 , the presence of paramastoid apophysis. In these four case reports, three were located on the left side and one bilaterally, this last presenting complete atlanto-paramastoid synostosis. To collaborate with the studies of apophysis paramastoid, the findings of this study found the presence of an apophysis 


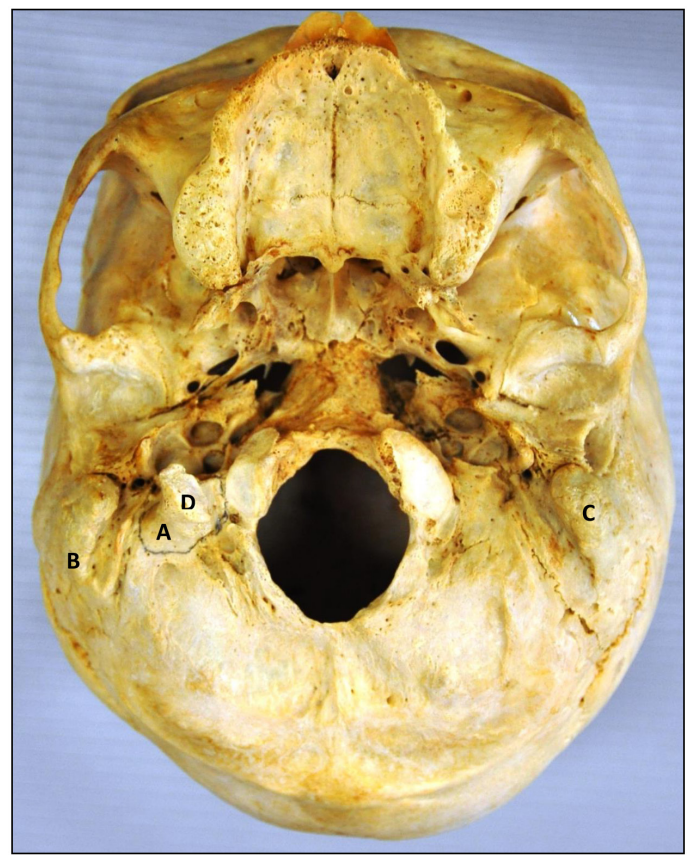

Figure 1. Inferior view of the skull. A - right paramastoid apophysis B-right mastoid process, C - left mastoid process, and D - Facet joint with transverse process of the atlas.

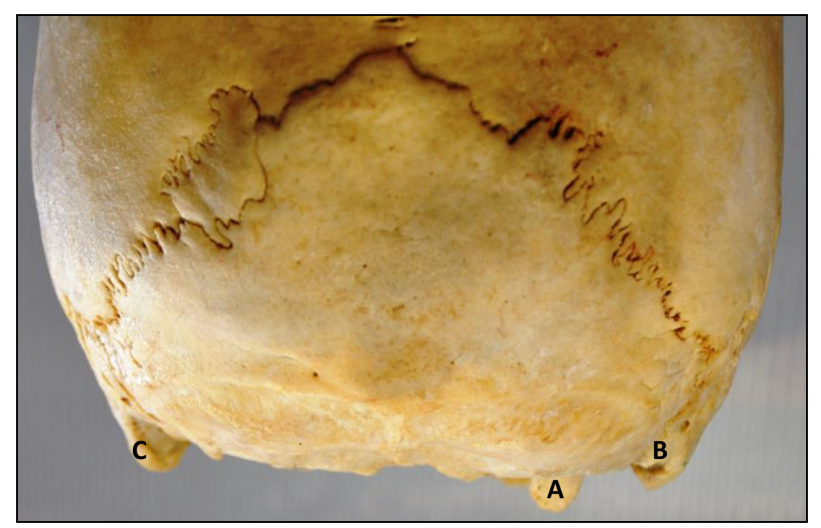

Figure 2. Posterior view of the skull. A - right paramastoid apophysis B-right mastoid process and C - left mastoid process.

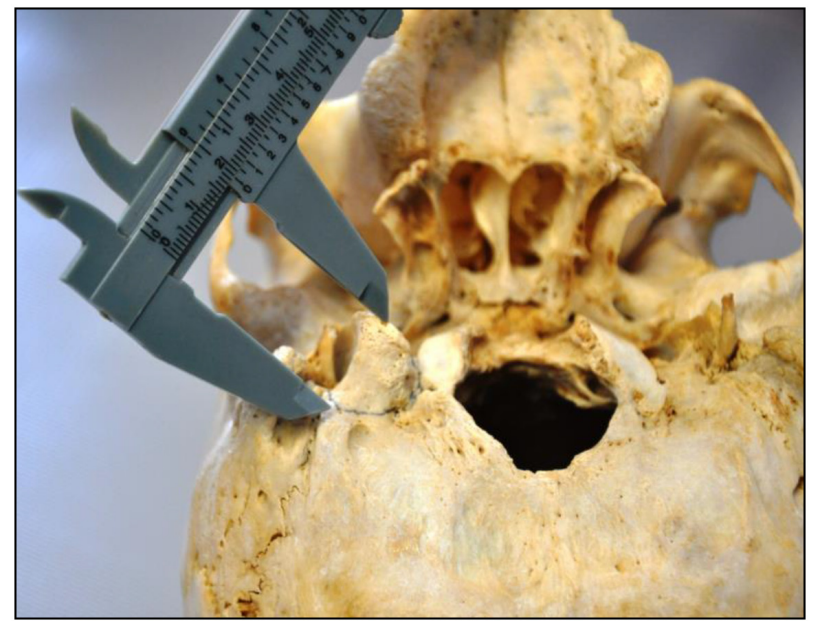

Figure 3. Measurement with a pachymeter of the height of the paramastoid apophysis on the right side. unilateral (right side), articular with the transverse processes of the atlas and $18.10 \mathrm{~mm}$ of elevation.

With regard to the justification for the appearance of the paramastoid apophysis, Testut and Latarjet (1975) reported the pathological character to its appearance and mentioned that what contributes to their occurrence is the ossification of part or all of the lateral rectus muscle of head, which generally lies between the jugular apophysis of occipital and the apophysis transverse of atlas. This muscle serves to flex the head and helps stabilize it (MOORE, DALLEY and AGUR, 2011).

Abnormalities of the craniocervical junction are of interest not only to anatomists but also for the doctors, because many of these malformations can produce neurological symptoms (FIGUEIREDO, MORAES, SERRA et al., 2008). As presented by Ferreira, in 2009 , that in a case of cervical myelopathy, the examination of pictures showed beyond the paramastoid apophysis, a malformation of the occipital joint and third condyle occipital.

\section{Conclusion}

This study will be important for the health sciences and those who keep interest in pathologies associated with atlanto-occipital joint, because the description of the structures that deviate from the normal organogenesis resulting from disorders: hereditary basis or not, has a practical interest that prints the modification to the arrangement of the constituent elements of the region and possible functional alterations resulting therefrom.

\section{References}

FIGUEIREDO, N., MORAES, LB., SERRA, A., CASTELO, S., GONSALES, D. and MEDEIROS, RR. Median (third) occipital condyle causing atlantoaxial instability and myelopathy. Arquivos de Neuro-Psiquiatria, 2008., vol. 66, n. 1, p. 90-92. http://dx.doi. org/10.1590/S0004-282X2008000100023. PMid:18392425.

LE DOUBLE, A. F. Traté des variations des os ducrane de I'homme. Paris: VIgot Fréres, 1903.

MANDARIM-DE-LACERDA, C. A. M. Métodos quantitativos em morfologia. São Paulo: Eduerj, 1995.

MASCITTI, TA. and STREJILEVICH, L. On the "paramastoid apophysis". Prensa Medica Argentina, 1961, vol. 48, n. 13, p. 829-835. PMid:13767735.

MOORE, KL, DALLEY, AF. and AGUR, AMR. Clinically oriented anatomy. 6th ed. Philadelphia: Wolters Kluwer Health, 2011.

TESTUT, L. and LATARJET, A. Tratado de anatomía humana. Barcelona: Salvat, 1975. 1237 p. Tomo I.

WILLIAMS, PL., BANNISTER, LH., BERRY, MM. et al. Gray anatomia. 37. ed. Rio de Janeiro: Guanabara Koogan, 1995. 606 p.

Received March 11, 2014

Accepted July 8, 2015 